Island Studies Journal, Vol. 9, No. 1, 2014, pp. 57-68

\title{
Islands and the offshoring possibilities and strategies of contemporary states: insights on/for the migration phenomenon on Europe's southern flank
}

\author{
Godfrey Baldacchino \\ University of Malta, Malta \\ godfrey.baldacchino@um.edu.mt
}

\begin{abstract}
Islands have transitioned from being conceived as prototypes of idealised polities to being deliberately engineered as offshore enclaves where the rules of the parent state need not fully apply. With their manageable size, separation and distance from the mainland, small islands are rendered as convenient laboratories for entrepreneurial political engineering, and equally handy sites for research on the same. Island migration policies manifest this contemporary flexibility and creative governance of states. As we approach the 500th anniversary of Thomas More's Utopia (1516), this paper explores these ideas in relation to the migration phenomenon on Europe's southern flank. Using an island studies approach, it discusses the problematique of island spaces caught in this dynamic but which cannot be 'offshore' because, as unitary island states (Cyprus and Malta) and unlike larger states with small outlying and peripheral island components (Italy and Australia), they must somehow be 'both inside and outside'. The paper goes on to critique such facile binarisms, arguing for a more nuanced appreciation of islands as well as a recognition that what may be, at face value, an expression of a state's authority is as much a manifestation of its limitations.
\end{abstract}

Keywords: Australia; Cyprus; Guantánamo; endoscapes; exoscapes; islands; Italy; Malta; migration; offshoring; political geography; xenoscapes

(C) 2014 - Institute of Island Studies, University of Prince Edward Island, Canada.

\section{Introduction}

The closest I have been to the status of a klandestin, was when I was mistaken for one.

It must have been early 1997, and my wife Anna and I - both amateur astronomers in our spare time - left our house on foot one late evening, with our two young boys (aged 12 and 6) in tow, to find a suitably dark site from where to observe Comet Hale-Bopp, then visible to the naked eye. The location is Marsaskala, Malta, a seaside town enjoying uninterrupted views across the Mediterranean, towards the east. We trekked gingerly down to a rocky area where we expected pitch dark conditions: it was a cloudless, moonless night, and with no hint of a breeze. We found a place where to sit; and waited for our eyes to adjust to night vision.

Suddenly, we heard footsteps, and coming from different directions. Two bright torches were flashed into our faces. A man's voice asked very firmly, in Maltese: "X'qed taghmlu?" (What are you up to?) I was too shaken to respond. Anna answered back, quite spontaneously: "X'qed taghmlu inthom?" (What are you doing?). By then, the figures had crept closer, and we could make out their camouflaged army fatigues. I also believe they were armed. With a few glances, they had checked us out, and one of the soldiers reported to the others: "Dawn orrajt. Familja maltija" (These are OK. It's a Maltese family.) We explained what we four were 


\section{G. Baldacchino}

doing, all alone in the dark. Before the soldiers left us, they told us that they were looking for klandestini; they had been tipped that some had landed by boat in the vicinity.

The encounter was not pleasant: we felt helpless and vulnerable to the soldiers and their authoritative practices; our eyes hurt with the sudden exposure to bright light; and at the same time, we felt relieved that we were 'OK' and could continue with our lives. But we were quite distraught and also felt insecure knowing that there may be actual klandestini in the area; we felt that the best thing to do was to head back home. The comet had to wait another day.

This is an episode where the sharp end of a state's regulatory and rudely dichotomous mechanism connects with the mobility strategies of a group of presumed undocumented migrants. It also predisposes natives to be wary and vigilant of such 'undesirables'. It is an encounter and a discourse that have repeated themselves, in various guises, on land as much as at sea, thousands of times; and with increasing sophistication, materiel and political panache of late, in the context of the drive for border securitization in the $21^{\text {st }}$ century (Bigo, 2008).

\section{This paper}

This paper serves as a synthesis to this special collection of papers; but it also advances an explicit island studies perspective to irregular maritime migration. It explores the parallel historical transition of islands (at least in the Western tradition) as both special places for the blest (engendering the notion of the ideotypical nation state) as well as excised spaces of detention for a motley set of undesirables. Most states today could, in principle, deploy the latter to impact on migrants: but, in practice, such excising and extra-territorialization has only been practised by the United States (in Guantánamo Bay, Cuba), in Australia (most notoriously on Christmas Island, but also subcontracted to other countries) and in Italy (on the islands of Lampedusa and Linosa). Cyprus and (more so) Malta, as self-contained sovereign island states, have no hinterland to excise, even if they wanted to. Moreover, they have been subjected to a 'distalization' of EU border policy (Mainwaring, 2012) possibly disproportionate to their size. In this way, this paper shows islands to be not just convenient microcosms of the same phenomena writ large elsewhere; but liable to their own idiosyncratic dynamics, which are only naively reduced to binary oppositions.

\section{From endotopias ...}

Thomas More's Utopia, an idealized jurisdiction of model government, had to be deliberately constructed as an (almost circular) island so that its geography would be as perfect as its political principles. In this way, utopia joined other island spaces that were engineered, materially or conceptually, in the Western mind to constitute mythical spaces of refuge, hope and civilization. From the sacred islands of Iona, Lindisfarne and Skellig Michael, to the fabled isles of St Brendan, Antillia and Hy Brazil, European writers and then cartographers historically or figuratively - used islands to preserve the Christian faith in times of extensive piracy and insecurity, to populate and provide beacons of safety and faith in uncharted Atlantic waters infested with demons and dragons, and to serve as physical and mental stepping stones in the timorous voyages across the unknown (Gillis, 2004; Johnson, 1994). Such texts as Bordone's isolario (1528), Porchacchi's 'island book' (1572), and Coronelli's isolario (1697) were atlases that presented an archipelagic concoction that comforted observers as much as navigators by offering refuge, supplies and repose ... much like the then prevalent concept of 
sanctuary on land (Gaudet, 2007). Moreover, the representation of islands as unified, bounded, naturally occurring cartographic entities presaged the idea of a similarly construed territorial state (Steinberg, 2005). Indeed, in the early modern period, islands came to represent quintessential platforms for nation-states: as delineated spaces, discrete bounded territories that are at once knowable and, because of their consolidated form, readily defensible, islands function as ideal embodiments of the state's relationship to the nation (Peckham, 2003, p. 503). Perhaps more so than in continental states, island boundaries express and define the inside and outside of a nation as a distinct, compact and cohesive social entity. The finite and self-evident island geography smoothens the nurturing of a sense of identity that is contiguous with territory (Anckar, 2005; Baldacchino, 2005; Srebrnik, 2004). In their "physicality, visibility and regularity", sea borders accentuate and colour the imagined tensions between the defensive and offensive functions prescribed by the boundary (Law, 2005, p. 267): their geography creates an 'inside' that is obviously distinct and marked off from the external world (Anderson, 1991). Islands thus provide natural grounds for the construction of independent states (think Iceland, Singapore, Malta) as much as for aggressive expansionism (think Great Britain, Japan, Venice). Such tropes help explain why only ten populated islands are today divided between more than one country (Royle, 2001, pp. 150-2; Baldacchino, 2013); and where, even amongst these ten, expectations of unitary governance remain salient (think Cyprus, Ireland, Sri Lanka, Timor). In the awesome 21 st century architectures of the Palm Jumeirah, Palm Jebel Ali, 'The World' and the Burj al Arab, off Dubai, we see examples of this pseudo-manufacture of perfect island spaces, mock havens restricted for the exclusive use of the wealthy, keen to seek refuge in gated communities (Jackson \& Della Dora, 2009; Junemo, 2004). And, in a less hubristic world, gripped by the impacts of anthropogenic climate change, 'green islands' like El Hierro (The Canaries, Spain) and Samsø (Denmark) offer tangible "geographies of hope" (Turner, 2007). This world is an endotopia, constituted of interiors: made up of sharply delineated spaces meant to protect their residents, aligning geography with history and culture (Cameron, 2012). The island here is a virtuous "enabling" space (Edmond \& Smith, 2003, p. 8).

\section{... to exotopias}

And yet, something else was happening, a series of policy measures that were positioning islands in a completely antithetical situation as outside spaces, turning the endotopia on its head. If a benign safe space befits and engenders the ideal state, then a maligned space is begotten by the strategically proactive state. We here venture into an archipelago of exotopia: now protecting those off the island from its transported, undesirable residents. The island becomes a dark, "disabling" space (Edmond \& Smith, 2003, p. 8). Hence, a parallel history of excision and de-territorialization: an exploitation of the smallness (hence manageability) and distancing (hence increased security) of island spaces to serve as sites of detention. The linkage of (often small) islands with prisons is an old one: pagans often located their demons offshore. Christianity locates its devils in Hell, which can be construed to be an island (Turner, 1993). Even in the magical Atlantic of the Middle Ages lurked the Isle of Demons (Johnson, 1994, Chapter 5). Dante Alighieri located his Inferno on an island in the Southern hemisphere. A graduated spatialization of fear has led to islands being favoured sites for xenotopias (Cameron, 2012): penal colonies, or even as wholesale prisons: Elba, then St Helena, incarcerated Napoleon; Devil's Island (in French Guiana) held, among many others, Alfred Dreyfus; Robben Island held Nelson Mandela; french political and religious detainees were 


\section{G. Baldacchino}

dumoed at the Chateau d'If, outside Marseilles; and Alcatraz - also known as Hellcatraz (Gardner, 1939) - held Al Capone. Apart from the penal colony on/of the Australian continent proper in the $19^{\text {th }}$ century, several of its offshore islands served as higher security prisons: Sarah, Melville, Stradbroke, Norfolk, Rottnest, and the quasi-island Tasman peninsula on Van Diemen's Land (now Tasmania) (Gillis, 2007; Pearn \& Carter, 1995; Royle, 2001, pp. 50-1). Like a macabre Matryoshka doll, a multiple insularity awaited the worst of the worst convicts.

Meanwhile, the definition of those to be detained expanded beyond demons and convicts: in 1423, Venice set up a lazaretto (quarantine station) on the island of Santa Maria di Nazareth near the city, and the Venetian system became a model for others to follow (Gensini, Yacoub, \& Conti, 2004, p. 259; Sehdev, 2002). This zoning practice, another type of containment, codified at law, was meant to ensure that communicable diseases that might have been contracted elsewhere - by naval crews, passengers and animals - would not spread to local populations. The surrounding sea limited the possibility of escape, and thus widespread contagion. Even earlier, an enclosing of distinct communities in ghettos - say, Jewish or Christian merchants in Muslim cities - permitted these some privileges (freedom of worship, tax exemption) counter-balanced by restraint (Abulafia, 2011, p. 646). Geographical convenience partly explains why many islands also ended up hosting, or becoming, hospitals that treated, as much as they enclosed, leprosy or contagious diseases (e.g. the "leper colony" of Molokai, Hawai'i, USA; and D'Arcy Island, off Vancouver Island, Canada (Holm, 2001).

But this condition needs to be coupled by the ability of a state not just to exercise control over territory (via force or legislative authority) but to actively hive off one or more regulatory regimes within its own space. Excising, zoning, detaching, niching, outbordering, dislocating, insulating, unbundling, quarantining and offshoring are some of the performative active verbs that can describe a clutch of different initiatives which, while diverse, share one intent: the endowment of a specific place within a state with particular and closely circumscribed privileges or penalties. These specialised services have led to various island detention camps and quarantine sites, but also, mainly in the 20th century, to offshore finance centres, low-tax havens, enterprise processing zones, geostrategic military bases, remote weapons test and dump sites, special autonomous regions, duty-free zones, heritage and conservation parks, spaces without right of abode, and various 'mix and match' combinations of the above. The physical and geographic boundedness and specificity of islands make these spaces both possible and appealing to their designers; they are often the default candidates of choice for such a thrust of political design that presupposes its own delineated distinctiveness. Simply and banally put, if one wishes to create or transform a place in order to endow it with the possibility of doing something exceptional, whether utopic or dystopic, and benefiting from both containment and distance, then that place should ideally be on an island, or be an island in toto. Meanwhile, the decisions to earmark such spaces in this manner would not be possible, feasible, or prudent if extended over a state's total territory and population. As a perfect and unitary island space, More's Utopia, while it is itself offshore to, and distinct from, its less idyllic mainland, cannot contemplate offshoring (Baldacchino, 2010).

\section{Three exceptional spaces, but not exceptions}

Sidaway (2007, p. 352) identifies a tendency on the part of modern-day states to condone a progressively more variegated and zonal capitalism; a "complex and uneven experience of selective boundary crossings, subjectivities and exclusions" Such an "unbundling of 
territoriality" enables a political system based on borders, sovereignty and territoriality to coexist with the "borderless world" (Ohmae, 1990; also Hudson, 2000, p. 276; Palan, 1998).

Hence we inhabit a political landscape that posits both inside and outside spaces, leaving considerable room for "creative governance", as various sub-national (and mainly island) jurisdictions attest (Baldacchino, 2010). Spaces that are representative and performative of offshoring strategies - and located in a "sort of outside" (Harvey, 2003, p. 14) - cannot be regarded as "anomalies, annoying or even amusing exceptions" (Stevens, 1977, p. 178). Echoing Georg Simmel's concept of strangerhood, whereby a stranger both defines and defies boundaries, we are faced with an ambivalent yet increasingly common concurrence of spatial detachment and attachment (Simmel, 1971, pp. 143-149, also Bauman, 1997, p. 17).

Expressions of such creative governance in relation to 'undesirable immigrants' were operationalised in the wake of the Tampa incident (Mares, 2002). On 26 August 2001, Tampa a Norwegian freighter, picked up 433 passengers and crew from the leaking Indonesian ferry KM Palapa and was later forced by asylum seekers (among those picked up) to head towards Christmas Island (a territory of Australia). Next day, the Howard government in Australia, supported by the Labour opposition, announced that Tampa would not be allowed to land in Australia or any other Australian territory. When, on 29 August, Tampa nevertheless entered Australian waters, special forces boarded the ship; its human cargo was eventually transferred to Nauru and New Zealand for 'processing'. On 11 September, an Australian Federal Court judge pronounced that the asylum seekers should be brought to Australia, they having been held on the vessel "without lawful authority" and in breach of common law (Saunders, 2001). The full bench of the Federal Court, however, overturned this decision within a week (Federal Court of Australia, 2001; Betts, 2001). Following this incident, the Australian legislature amended the Migration Act in order to limit the country's obligations with respect to migrants: it designated over 4,800 portions of sovereign territory - including Christmas Island, Ashmore Reef, Cartier Islands and the Cocos (Keeling) Islands - as 'non-Australia' for the strict purpose of claiming asylum (Connell, 2006, p. 55). Moreover, the sovereign states of Nauru and Kiribati were designated by the same federal act as "offshore processing centres" (read: immigration-detention facilities) for refugee claimants in Australia (Foster \& Pobjoy, 2011).

Moral and ethical issues apart, this so-called 'Pacific Solution' illustrates at least two key lessons in creative jurisdictional praxis. First, is a process of state regulatory contraction: the manner in which a (typically large) country - in this case, Australia - can deliberately reengineer the identity of some of its component units in the interests of 'national security' via a process of selective 'de-territorialization' (Perera, 2007, p. 203). Spaces that are already physically and psychologically offshore, and with sparse or no resident populations, are ideal candidates to be also rendered legally so. Second, is an oppositional process of state regulatory expansion: other countries - in this case, the sovereign island states of Nauru and Kiribati, and eventually also Papua New Guinea - have taken on a set of tasks and services for Australia, another state, in exchange for payment. This suggests the status of a feudal fiefdom or a 'tributary state', and not of a modern sovereign entity. The onshore space of one sovereign country becomes, perversely, the offshore space of/for a totally different one.

The idea for the legal creation of 'non-Australia' probably came from the example of another jurisdictional exclave located on an island state, today with a notorious reputation: in the 1980s and early 1990s, refugee claimants (mainly from Haiti, but also from Cuba itself) held at Guantánamo Bay were denied any rights to appeal for asylum on the grounds that they were in a "lawless enclave" outside US jurisdiction (Kaplan, 2005, p. 839; McBride, 1999). 


\section{G. Baldacchino}

Guantánamo Bay has effectively been crafted and described as a "juridical limbo", a "black hole", "zone of indetermination" and a "carefully constructed legal absence"; it is a threshold where the border between inside and outside is deliberately ambiguous and uncertain (Bigo, 2007, pp. 17-18; Fletcher, 2004; Reid-Henry, 2007, p. 630).

If Guantánamo Bay was the inspiration to Australia's excised archipelago, then it is likely that the Australian case inspired Italy with regard to Lampedusa. The southernmost point of Italy, this small island (land area: $20 \mathrm{~km}^{2}$ ), lies $205 \mathrm{~km}$ from the island region of Sicily (of which it forms part administratively) but only113 km from Tunisia. It is now best known as a key entry point to Europe for immigrants (rendered irregular) from Africa, as well as escapees from the turmoil of regime change in Tunisia and Libya. Thousands have attempted the dangerous Mediterranean crossing; survivors picked up by the Italian coast guard were placed in a detention centre on Lampedusa prior to being transferred elsewhere in Italy for processing. In 2008, Italy ranked as the fourth-highest asylum host country in the industrialised world, trailing only the US, Canada and France (UNHCR, 2008, p. 6). In August of that year, however, Italian Prime Minister Berlusconi stopped this practice by externalising Italy's borders to Libya "in the same way that Australia is externalizing our border to Indonesia" (Curr, 2009). Following a US\$5-billion deal with the Gaddafi government in Libya, the international waters between the two countries were more vigorously policed by joint naval patrols; many immigrants rescued at sea were returned to Libya, contrary to international refugee rights. The UNHCR (2009) expressed "deep concern" about this practice, as with the state of detention facilities on Lampedusa. The number of migrants attempting the Mediterranean voyage fell dramatically since the Italy-Libya pact came into force (Human Rights Watch, 2009), increased again with the 'Arab Spring' and the collapse of the Gaddafi regime (2011), and has allegedly fallen again since: new governments in Tunisia and Libya have signed agreements with Italy "to help keep migrant traffic down" (Thornburgh, 2012).

Lampedusa stands as a blight on Europe: an outpost of the EU where normal rules do not apply. Increasingly, governments around the world appear to be adopting an 'out of sight, out of mind' approach to these kinds of outposts: whether in the Australian desert, a military base on Cuba or small islands across the Mediterranean Sea (Messineo, 2005).

These three deliberately excepted island spaces are not alone: today we have places which are both inside and outside the law, designed to isolate, contain and punish. Asylum seekers are some of their key intended targets (Kumar Rajaram, 2007). Such a technology of excision produces "spaces of exception": that manifest partial yet legalised lawlessness, via the very same exercise of sovereignty (Agamben, 2005). In the present imperial and neoliberal moment, where states are obliged to remove many barriers to trade and the free movement of goods, and who often find themselves looking helplessly at the free movement of capital and finance, states will exercise discretion on the free movement of people: we ought thus to expect more Guantánamo Bays, not fewer (Butler, 2002).

\section{But: life is less neat than binaries suggest}

Yet, island life cannot, and should not, be reduced to simple, and simplistic, binaries: of inside and outside, of us and them, of paradises and prisons, of routes and roots, of stasis and 
mobility. And especially so in dealing with a subject as irregular migration. Small they may be, and convenient laboratories they may be as well; but islands are not one-dimensional caricatures of larger spaces. We are, after all, dealing particularly with multiple categories of irregular migrants, who can be processed in a variety of different ways, including those that bestow more or less mobility; we are dealing with islands that are outposts, borderlands, hubs of circulation and places of settlement, possibly to different migrants; but also to the same migrants at different points in time (Triandafyllidou, 2014; Bernardie-Tahir \& Schmoll, 2014); we are also dealing with barriers, frontiers and prisons where - like all guarded spaces - there are gates, doors, windows and other escape routes. Practise power-as-discipline, reminds us Foucault (an inspiration to various papers in this collection) and we invariably experience resistance; this is no ontological opposition. Malta may have intercepted some 19,000 klandestini over the past decade; but only 5,000 remain; some have 'disappeared', slipped through the cracks of the sentinel island to continue their life in continental Europe, perhaps? Pace Loyd and Mountz (2014), and without diminishing the tragic sense of loss that this involves, disappearance is not just a consequence of death by drowning. Such a permeability and porosity inherent to total institutions - and to which states are loathe to admit - allows us to combine and meld the overall (and itself binary) architecture that has driven this special collection: that of islands as objects of distalization (Mainwaring, 2012), policing and bordering; as much as translocal and interstitial spaces (Bernardie-Tahir \& Schmoll, 2014).

\section{The particular predicament of Cyprus and Malta}

In the Mediterranean, the three larger EU member states that are targets of migration - Spain, France and Greece - could (like Italy and its Lampedusa) excise part of their, especially island, territories - such as the Canaries, the Balearics and the enclaves of Ceuta and Melilla (Spain), Corsica (France), and various Aegean islands close to the Turkish mainland (Greece) - to deny immigrants landed there from the right to demand refugee status. That these countries have not done so (yet) - opting instead to use 'onshore' facilities, like international airports, for the practice of more standard excision policies (Moseley, 1999) - suggests that they are not under extreme duress to stop the influx of immigrants, or they may still wish to uphold their obligations at international law and refrain from earning the rebuke of civil rights groups.

But: two other countries can only transit migrants in very limited numbers and would find it difficult to practise excision, even if they wanted to. These are Malta and Cyprus. Unlike all the other EU member states involved as destinations for clandestine migration, both Malta and Cyprus lack those jurisdictional geographies that - at least officially - would permit them (like the Canaries, Corsica, Sicily or Lesbos) to act as stepping stones, "interstitial spaces" (López-Sala \& Sánchez, 2010, p. 78) through which migrants arrive but also sooner (rather than later) depart to other (mainland) parts of the same state. Nor do these countries have the material physicality to practise excision: Cyprus is a single island (though internally highly fractured) state; while Malta, though an archipelago, is a compact island group where distances between the three main islands are not prohibitive enough to prevent 'escape', or to render any excised activities 'out of the public eye'. While there is one main island (also called Malta), the remaining two (Gozo and Comino) are not offshore enough.

Other issues impact exclusively on compact island states and their experience of immigration. Since they have absolutely no land borders, the first contact of clandestine immigrants with Malta and Cyprus is generally at sea (no pun intended): often in international 


\section{G. Baldacchino}

waters far away from the immigrants' port of departure. This means that the Cypriot or Maltese maritime units are less able to oblige such immigrants to turn back and head back to where they started their sea journey. Rather, their encounter is typically one of 'rescue', of providing food, water, emergency medical supplies and treatment from dehydration and disease. Such care beyond immediate first aid typically involves landing because it may need to be continued at proper, land-based, medical facilities. The engagement of Maltese and Cypriot maritime units with clandestine immigrants is therefore essentially more of a basic humanitarian one at that point. In contrast, processing at a land border post carries the distinct and viable option of refused entry to the applicant and turning him/her back, with often no such serious repercussions on his/her immediate health and survival. Moreover, once landed in Cyprus or Malta, there is no hinterland to which irregular immigrants can be despatched: both these countries (and Malta more so) have - as their politicians are likely to remind us - limited land areas and relatively high population densities; though they still do their best to locate their detention camps out of the public eye. This situation further reduces the room for manoeuvre available to the Cypriot and Maltese authorities in the face of irregular immigration. No wonder then that Cyprus and Malta disagree with the basic provisions of the Dublin II agreement whereby an irregular migrant's application for asylum is to be handled by the EU member state where that migrant first arrived. While meant to prevent 'asylum shopping', (migrants seeking asylum in different countries at the same time), these regulations have allegedly created a lopsided burden on border countries, and especially Malta (Sansone, 2011).

There is another interesting twist to the irregular migrant story: the increase of nationalist sentiment in both Malta and Cyprus. Former British colonies, both island states sought integration with a larger metropolitan state before securing independence: Malta sought integration with a reluctant Britain, while Greek Cypriots sought enosis (union) with Greece (even as Turkish Cypriots sought a two-state division [taksim] as the best guarantee for their civil rights). Such historical events belie an absent sense of local nationalism, perhaps even evidence that these may be "nationless states" (Baldacchino, 2002, on Malta), lacking unifying symbols that cut across racial, ethnic or partisan solitudes. The arrival of often dark-skinned, often non-Christian, irregular immigrants has triggered an appeal to, and a nostalgia for, a mythical depiction of nationhood in both island states: one premised on the national character as solidly white-skinned, racially pure, European and Christian (Catholic in Malta; Greek Orthodox in Cyprus), and with the converse distrust and fear of the 'Other' (Baldacchino, 2009). Hence a xenophobic culturescape unfolds: an exoscape riddled with negative affect, a suspicion or outright dislike of the stranger; even though such dynamics are not borne out by a long history of Mediterranean exchange (Braudel, 1972). We must remember that only recent laws and regulations have created classes of legal, illegal or irregular migrants, in a maritime region that has ironically thrived for centuries (prior to the emergence of the modern, securitybedevilled state) from open trade and movement (Abulafia, 2011).

\section{Conclusion}

Just like More's Utopia, Malta and Cyprus, it seems, can only be endoscapes: they serve as interiors (as sovereign states and as constituents of the European Union to both their own citizens and immigrants). While as states they could both flex their jurisdictional capacities in an offshoring manner, they both lack the geophysical materiality to be able to do so effectively. Yet, ironically enough, the tenets of the Dublin II agreement allow the EU to exploit its 
southern border states (including, but not only, Cyprus and Malta) as quasi-excised zones, obliging them to keep the many undocumented migrants crossing into Europe from North Africa and the Middle East who are aspiring for asylum status stuck in their home territory. And yet, only for Malta and Cyprus, very limited off-island migration is officially possible.

Returning to Cameron: "... the myth of national sovereignty that we all live with is grounded in an island-derived, utopic notion of selective openness-closure" (2012, p. 743). While national sovereignty presupposes a world of equal players respectful of each others' status and territorial rights, there remains lots of room for manoeuvre, a resort to selectivity as to the extent to which a state is closed/open, for whom, and for what purpose. The idea is similar to that of Foucault's notion of governmentality whereby states, no longer concerned as much these days with threats to their very existence, can flex their clout intra and extraterritorially, and in so doing provide new and creative opportunities for the exercise of sovereignty (Foucault, 1991, p. 93; Kuehls, 1996, p. 67; Baldacchino, 2012); a performative act of government-as-agency. In these, often post-colonial "sovereignty games" (Adler-Nissen $\& \mathrm{Gad}, 2013$ ), notions of race, nationhood and ethnicity are important constructs; and migrants unwittingly serve as the heterotopia to unfold these constructs in suggestive ways.

And yet, all power leaks: nor does one play the game according to the same rules, or even play the same game. Migrants exercise mobility in ways central to the unfolding of sovereignty (Loyd \& Mountz, 2014): if my family and I have been deemed "OK" by the patrolling Maltese soldiers back in 1997, then others were "not OK", and would engage the state bureaucracy in specific rituals (Falzon, 2010) if caught. Migrant mobilities and practices, like their identities, are messy and complex; they include consent and compliance, and voice and exit strategies. In all this, the symbolic "small island' serves as a manageable research site, a transitional space of flows, a carceral coffer at various scales, a sovereign state with reduced policy options, but still a deeply ambiguous entity with its own sui generis terraqueousness.

\section{References}

Abulafia, D. (2011). The great sea: A human history of the Mediterranean. London: Allen Lane. Adler-Nissen, R., \& Gad, U. P. (Eds.) (2012). European integration and postcolonial sovereignty games: EU's Overseas Countries and Territories. London: Routledge.

Agamben, G. (2005). State of exception. Translated by K. Attell. Chicago, IL: University of Chicago Press.

Anckar, D. (2005). Decentralization in microstates: where, how and why? Canadian Review of Studies in Nationalism, 32(1-2), pp. 109-120.

Anderson, B. (1991). Imagined communities: Reflections on the origins and spread of nationalism. London: Verso.

Baldacchino, G. (2002). The nationless state? Malta, national identity and the European Union. West European Politics, 25(4), pp. 191-206.

Baldacchino, G. (2009). Pangs of nascent nationalism from the nationless state? Eurocoins and undocumented migrants in Malta, post-European Union membership. Nations and Nationalism, 15(1), pp. 148-165.

Baldacchino, G. (2010). Island enclaves: Offshoring strategies, creative governance and subnational island jurisdictions. Montreal QC: McGill-Queen's University Press. 


\section{G. Baldacchino}

Baldacchino, G. (2012). Governmentality is all the rage: the sovereignty experience of small jurisdictions. The Round Table: Commonwealth Journal of International Affairs, 101(3), pp. 235-251.

Baldacchino, G. (Ed.) (2013). A political economy of divided islands: Unified geographies, multiple polities. New York: Palgrave Macmillan.

Bauman, Z. (1997). Postmodernity and its discontents. Cambridge: Polity Press.

Betts, K. (2001) Boat people and public opinion in Australia. People and Place, 9(4), pp. 34-48.

Bigo, D. (2008). International political sociology of security. In P. D. Williams (Ed.) Security studies: An introduction (pp. 116-129). New York: Routledge.

Bigo, D. (2007) Detention of foreigners, states of exception, and the social practices of control of the panopticon. In P. K. Rajaram \& C. Grundy Warr (Eds.) Borderscapes: Hidden geographies and politics at territory's edge (pp. 3-34). Minneapolis MN: University of Minnesota Press.

Braudel, F. (1972). The Mediterranean and the Mediterranean world in the age of Philip II. Vol. I. Translated by Siân Reynolds. London: Collins.

Butler, J. (2002). Guantánamo limbo. The Nation, 1 April. Retrieved from http://www.thenation.com/doc/20020401/butler

Cameron, A. (2012). Splendid isolation: philosophers' islands and the (re-)imagination of state space. Geoforum, 43(4), pp. 741-749.

Connell, J. (2006). Nauru: the first Pacific failed state? The Round Table: Commonwealth Journal of International Affairs, 95(383), pp. 47-63.

Curr. P. (2009). We can do better than Italy's warehousing on Lampedusa. Brisbane Times, 14 October. Retrieved from http://www.brisbanetimes.com.au/opinion/politics/ e-can-dobetter-than-italys-warehousing-on-lampedusa-20091014-gwh8.html

Edmund, R., \& Smith, V. (2003). Editors' introduction. In R. Edmond \& V. Smith (Eds.) Islands in history and representation (pp. 1-18). London: Routledge.

Falzon, M. A. (2010). Immigration rituals and transitoriness in the Mediterranean island of Malta. Journal of Ethnic \& Migration Studies, 38(10), pp. 1660-1680.

Federal Court of Australia. (2001). Minister for Immigration and Multicultural Affairs and Ors v Eric Vadarlis V1007 of 2001, and Minister for Immigration and Multicultural Affairs and Ors v Victorian Council for Civil Liberties Incorporated and Ors V1008 of 2001.

Fletcher, G. P. (2004). Black hole in Guantánamo Bay. Journal of International Criminal Justice, 2(1), pp. 121-132.

Foster, M., \& Pobjoy, J. (2011). A failed case of legal exceptionalism? Refugee status determination in Australia's 'excised' territory. International Journal of Refugee Law, 23(4), 583-631.

Foucault, M. (1991). Governmentality. In G. Burchell, C. Gordon \& P. Miller (Eds.) The Foucault effect: Studies in governmentality (pp. 87-104). Chicago IL: University of Chicago Press.

Gardner, R. (circa 1939). Hellcatraz: The rock of despair (Alcatraz). Self-published.

Gaudet, L. (2007). Safe haven: The possibility of sanctuary in an unsafe world. Toronto ON: Random House.

Gensini, G., Yacoub, M., \& Conti, A. (2004). The concept of quarantine in history: from plague to SARS. Journal of Infection, 49(4), pp. 257-276.

Gillis, J. R. (2007). Escape to Alcatraz: islands in the landscape of fear. Paper presented at 3rd international conference on small island cultures, Charlottetown, Canada, June. 
Gillis, J. R. (2004). Islands of the mind: How the human imagination created the Atlantic world. New York: Palgrave Macmillan.

Harvey, D. (2003). The new imperialism. Oxford: Oxford University Press.

Holm, B. (2001). Eccentric islands: Travels real and imaginary. Minneapolis: Milkweed Press.

Hudson, A. C. (2000). Offshoreness, globalization and sovereignty: a post-modern geo-political economy? Transactions of the Institute of British Geographers, 25(3), pp. 269-283.

Human Rights Watch. (2009). Pushed back, pushed around. 21 September. Retrieved from http://www.hrw.org/en/node/85582/section/1

Jackson, M., \& Della Dora, V. (2009). 'Dreams so big only the sea can hold them': man-made islands as anxious spaces, cultural icons and travelling visions. Environment \& Planning A, 41(9), pp. 2086-2104.

Johnson, D. S. (1994). Phantom islands of the Atlantic. Fredericton NB: Goose Lane.

Junemo, M. (2004). Let's build a Palm island! Playfulness in complex times. In M. Sheller \& J. Urry (Eds.) Tourism mobilities: Places to play, places in play (pp. 181-191). London: Routledge.

Kaplan, A. (2005). Where is Guantánamo? American Quarterly, 57(3), pp. 831-858.

Kuelhs, T. (1996). Beyond sovereign territory. Minneapolis MN: University of Minnesota Press.

Kumar Rajaram, P. (2007). Locating political space through time: asylum and excision in Australia. In P. K. Rajaram \& C. Grundy-Warr (Eds.) Borderscapes: Hidden geographies and politics at territory's edge (pp. 263-282). Minneapolis: University of Minnesota Press.

Law, A. (2005). Of navies and navels: Britain as a mental island. Geografiska Annaler, 87B(4), pp. 267-277.

López-Sala, A., \& Sánchez, V.E. (2010). La nueva arquitectura política del control migratório em la frontera marítima del Suroeste de Europa: los casos de España y Malta. In M. E. Anguiano \& A. M. López Sala (Eds.) Migraciones y fronteras: Nuevos contornos para la movilidad internacional (pp. 75-102). Barcelona, Spain: Icaria Antrazyt CIDOB.

Loyd, J. M., \& Mountz, A. (2014). Managing migration, scaling sovereignty on islands. Island Studies Journal, 9(1), pp. 23-42.

Mainwaring, C. (2012). Resisting distalization? Malta and Cyprus' influence on EU migration and asylum policies. Refugee Survey Quarterly, 31(4), pp. 38-66.

Mares, P. (2002). Borderline: Australia's response to refugees and asylum seekers in the wake of the Tampa. Sydney, Australia: University of New South Wales Press.

McBride, D. (1999). Migrants and asylum seekers: US policy responses to immigrants and refugees from Central America and the Caribbean. International Migration, 37(1), pp. 289-317.

Messineo, F. (2005). Italy: Lampedusa, the island of Europe's forgotten promises. Amnesty International, 6 July. Retrieved from http://www.amnesty.org/ar/library/asset/EUR30/008/2005/en/94ac3cc7-d4ce-11dd-8a23d58a49c0d652/eur300082005en.pdf

Moseley, R. (1999). Airport news: refugee refuses to leave his Paris airport home. Chicago Tribune. 21 September. Retrieved from http://archives.californiaaviation.org/airport/msg02138.html

Ohmae, K. (1990). The borderless world: Power and strategy in the inter-linked economy. New York: Harper Collins.

Ong, A. (2004). The Chinese axis: zoning technologies and variegated sovereignty. Journal of East Asia Studies, 4(1), pp. 69-96. 


\section{G. Baldacchino}

Palan, R. (1998). Trying to have your cake and eating it: how and why the state system has created offshore. International Studies Quarterly, 42(4), pp. 625-643.

Pearn, J., \& P. Carter (1995). Islands of incarceration: Convict and quarantine islands of the Australian coast. Brisbane, Australia: Amphian Press.

Peckham, R. S. (2003). The uncertain state of islands: national identity and the discourse of islands in $19^{\text {th }}$-century Britain and Greece. Journal of Historical Geography, 29(4), pp. 419-515.

Perera, S. (2007). A Pacific zone? Security, sovereignty and stories of the Pacific borderscape. In P. Kumar Rajaram \& C. Grundy-Warr (Eds.) Borderscapes: Hidden geographies and politics at territory's edge (pp. 201-227). Minneapolis: University of Minnesota Press.

Reid-Henry, S. (2007). Exceptional sovereignty? Guantánamo Bay and the re-colonial present, Antipode, 39(4), pp. 627-648.

Royle, S. A. (2001). A geography of islands: Small island insularity. London: Routledge.

Sansone, K. (2011). Asylum ruling 'strengthens' Malta's stand for change. Sunday Times of Malta, January 23. Retrieved from http://www.timesofmalta.com/articles/view/20110123/local/asylum-ruling-strengthensmalta-s-stand-for-change.346623

Saunders, M. (2001). Take boat people back, court orders. The Australian, 12 September, 4.

Sehdev, P. S. (2002). The origin of quarantine. Clinical Infectious Diseases, 35(9), pp. 10711072.

Sidaway, J. D. (2007). Spaces of postdevelopment. Progress in Human Geography, 31(3), pp. 345-361.

Simmel, G. (1971). On Individuality and social forms: Selected writings. Edited by D. Levine. Chicago IL: University of Chicago Press.

Srebrnik, H. F. (2004). Small island nations and democratic values. World Development, 32(2), pp. 329-342.

Steinberg, P. E. (2005). Insularity, sovereignty and statehood: the representation of islands on Portolan charts and the construction of the territorial state. Geografiska Annaler, 87B(4), pp. 253-265.

Stevens, R. M. (1977). Asymmetrical federalism: the federal principle and the survival of the small republic. Publius: The Journal of Federalism, 7(4), pp. 177-203.

Thornburgh, N. (2012). Breaching fortress Europe: despite the downturn, migrants brave fatal crossing. Time World, 28 August. Retrieved from http://world.time.com/2012/08/28/breaching-fortress-europe-despite-the-downturnmigrants-still-brave-a-fatal-crossing/

Triandafyllidou, A. (2014). Multi levelling and externalising migration and asylum: lessons from the southern European islands, Island Studies Journal, 9(1), pp.7-22.

Turner, A. K. (1993). The history of hell. New York: Harcourt Brace Jovanovich.

Turner, C. (2007). The geography of hope: A tour of the world we need. New York: Random House.

UNHCR (2008). Asylum levels and trends in industrialized countries. Retrieved from http://www.unhcr.org/49c796572.html

UNHCR (2009). UNHCR deeply concerned over returns from Italy to Libya. Media release, 7 May. Retrieved from http://www.unhcr.org/4a02d4546.html 